Gandhi, S. S., Grasty, R. L. \& Grieve, R. A. F. 1969: The geology and geochronology of the Makkovik Bay area, Labrador. Can. J. Earth Sci. 6, 1019-1035.

Taylor, F. C. 1969: Reconnaissance geology of a part of the Precambrian Shield, northeastern Quebec and northern Labrador. Pap. geol. Surv. Can. 68-43.

Wheeler, E. P. Ind 1960: Anorthosite adamellite complex of Nain, Labrador. Bull. geol. Soc. Am. 71, 1755-1762.

Windley, B. F. in press: The anorthosites of southern West Greenland. Mem. Am. Ass. Petrol. Geol. 12.

\title{
A COMPILATION OF K/AR AGE DETERMINATIONS ON ROCKS FROM GREENLAND CARRIED OUT IN 1969
}

\section{Bridgwater}

In order to relieve the pressure of routine work on the age dating laboratories in the University of Copenhagen and other institutes working in collaboration with GGU, it was decided to send out samples for K/Ar age determination by a firm of consultants*. The problems selected for study were generally of a regional character - for example the basic dyke chronology from SW Greenland - or were preliminary studies of rocks from areas where little isotopic age work had been carried out previously. Much of the material used was far from ideal for accurate determination of a particular event, the selection of samples having been controlled by geological criteria rather than the suitability for precise isotope measurement. The results are therefore to be regarded as pointers for future detailed studies rather than as having given definitive answers. Several of the determinations show the presence of excess argon, sometimes in considerable amounts. The possible geological implications of this are discussed briefly at the end of this note. The ages quoted are averages based on several determinations on each sample. Full analytical data is available on request from GGU. The constants used for calculation of the ages are

$$
\begin{aligned}
& \lambda_{\mathrm{e}}=0.584 \times 10^{-10} \mathrm{yr}^{-1} \\
& \lambda \beta=4.72 \times 10^{-10} \mathrm{yr}^{-1}
\end{aligned}
$$

* FM Consultants Ltd., 21 Harcourt Drive, Herne Bay, England. 
Late Precambrian and Phanerozoic minor intrusions

North Greenland

$72.2 \pm 9.0 \mathrm{~m} . \mathrm{y}$. whole rock (mean of 3 determinations)

GGU 114166. A NW-SE trending alkali olivine dolerite from the Midsommersø area, southern Peary Land. $82^{\circ} 12^{\prime} \mathrm{N}, 33^{\circ} 03^{\prime} \mathrm{W}$. H. F. Jepsen

One of the regional swarm of basic dykes cutting Lower Cambrian sediments in southern Peary Land (see Henriksen \& Jepsen, this report). The sample shows serpentine, chlorite and sericitic alteration although there is fresh olivine preserved. The alteration is regarded as essentially deuteric as there are no geological grounds for believing that the area has been affected by a younger thermal event. The $\mathrm{K} / \mathrm{Ar}$ age is regarded as a minimum age for the intrusion of the dyke.

\section{South and West Greenland}

$57.2+1.1 \mathrm{~m}$. y. whole rock ( 3 determinations)

GGU 110953. An E-W altered basic or intermediate dyke from Godthåbsfjord. $64^{\circ} 05^{\prime} \mathrm{N}, 51^{\circ} 21^{\prime} \mathrm{W}$.

V. R. McGregor

A $1.5 \mathrm{~m}$ composite dyke with a late pale centre from which the sample was collected enclosed by a zeolite-bearing darker margin. The dyke is one of the younger members in the E-W swarm of late minor intrusions in Godthåbsfjord which post-date the faulting and which include the so-called "red dykes". All the dykes examined show strong alteration and are mildly alkaline in nature. The alteration is thought to be closely related to their injection. The $\mathrm{K} / \mathrm{Ar}$ age may be presumed to be that of the strong alteration of the dykes.

\section{$168 \pm 5 \mathrm{~m} . \mathrm{y}$. biotite ( 3 determinations)}

GGU 33937. Biotite megacryst from augite-biotite lamprophyre dyke, Frederikshåb district. $62^{\circ} 23^{\prime} \mathrm{N}, 49^{\circ} 22^{\prime} \mathrm{W}$.

A. K. Higgins

A $1 \mathrm{~m} \mathrm{E-W} \mathrm{lamprophyre} \mathrm{with} \mathrm{conspicuous} \mathrm{euhedral} \mathrm{augite} \mathrm{and} \mathrm{biotite} \mathrm{crystals} \mathrm{set} \mathrm{in}$ a fine-grained matrix containing small zeolite-filled cavities. The matrix is almost completely fresh, containing both corroded and euhedral pyroxenes, carbonated olivines, groundmass biotite, $\mathrm{Fe}$ oxides and a devitrified brown glassy base. Material for determination was taken from the cores of the biotite megacrysts.

The K/Ar age obtained is regarded as close to the date of intrusion of the body. It would therefore appear to belong to the same period of intrusion as the lamprophyre dyke from further west in the Frederikshåb area dated as $162 \pm 5 \mathrm{~m}$. y. (Larsen \& Møller, 1968; Walton, 1966; see also Allaart et al., in press, and Watt, 1969 for a discussion of the significance of this event). 
$212 \pm 5 \mathrm{~m}$. y. whole rock (3 determinations)

GGU 33822. Lamprophyre sill from Igdlukasik, Julianehåb district. $60^{\circ} 48^{\prime} \mathrm{N}, 46^{\circ}$ $20^{\prime} \mathrm{W}$.

J. H. Allaart

A slightly altered camptonitic sill (Upton, 1965) shown in the field to be older than the late Mesozoic swarm of coast-parallel dykes of SW Greenland (Watt, 1969) but younger than Gardar (c. $1100 \mathrm{~m}$. y.) intrusions. Alteration products include calcite, chlorite, sericite and clay minerals. These are regarded as deuteric. The K/Ar age suggests that these sills are no longer to be regarded as late members of the Gardar igneous activity. There are no geological grounds for suggesting that the $\mathrm{K} / \mathrm{Ar}$ age of this rock differs significantly from its date of intrusion.

\section{$202 \pm 6 \mathrm{~m} \cdot \mathrm{y} \cdot{ }^{40} \mathrm{Ar} /{ }^{39} \mathrm{Ar}$ whole rock (2 determinations)}

GGU 39654. Kimberlite sill cutting the Tigssaluk Granite, Ivigtut area. $61^{\circ} 26^{\prime} \mathrm{N}$, $48^{\circ} 26^{\prime} \mathrm{W}$.

C. H. Emeleus

An olivine-bearing kimberlite sill younger than all other rocks mapped in the immediate surroundings. Severe carbonate alteration of the sample is presumed to be essentially deuteric. The material used for analysis was taken from the least altered part of the sample and consists of anhedral olivines and small subhedral oxides in a plexus of biotite laths and carbonate. The isotopic age obtained can only be regarded as a minimum age for the emplacement of this body. It could possibly belong to the same period of minor intrusions as the sill mentioned above (GGU 33822). However petrologically the sill shows more marked similarities with the kimberlite dyke from the Frederikshåb area (GGU 72502) described below.

\section{$609 \pm 36 \mathrm{~m} . \mathrm{y}$. whole rock ( 3 determinations)}

GGU 72502. Kimberlite dyke trending 135, Frederikshåb district. $62^{\circ} 03^{\prime} \mathrm{N}, 48^{\circ}$ $52^{\prime} \mathrm{W}$.

S. Bak Jensen and J. R. Andrews

An almost completely fresh 1-2 m wide kimberlite dyke with peridotite nodules (Andrews, 1969). The dyke consists of rounded fresh olivine grains, phlogopite mica flakes and granules of $\mathrm{Fe}$ oxide in an anhedral carbonate matrix. There is slight deuteric alteration. Comparable lamprophyric and carbonatitic minor intrusions which also give similar K/Ar ages occur on the Labrador coast at Makkovik (Leech et al., 1963) and in the Umanak district of West Greenland (Larsen \& Møller, 1968). The present evidence suggests that the Frederikshåb kimberlite dykes are part of a scattered province of carbonatitic minor intrusions which occur over a large part of the North Atlantic Shield. However it is known that $\mathrm{K} / \mathrm{Ar}$ ages on similar rocks from other areas are commonly greater than the actual geological age of intrusion and it is clear that the minor intrusions of this type which occur sporadically in West Greenland are worth a special isotopic study on their own. 


\section{Precambrian basic minor intrusions}

North Greenland

$$
799 \pm 68 \mathrm{~m} \text {. y. whole rock ( } 3 \text { determinations) }
$$

GGU 114156. Altered dolerite from Midsommers $\varnothing$ area, $82^{\circ} 15^{\prime} \mathrm{N}, 33^{\circ} 28^{\prime} \mathrm{W}$.

H. F. Jepsen

A pre-tillitic sill cutting the apparently unmetamorphosed sandstones in the Precambrian sedimentary succession of southern Peary Land (Jepsen, 1969). Both this and the sample described below (GGU 114091) show strong alteration with the feldspars almost completely destroyed. If it is assumed that the sandstones are the lateral equivalent to the youngest sediments of the Carolinidian geosynclinal succession exposed further to the east then the ages given by these rocks give a minimum age for the Carolinidian sedimentation. If it is further assumed that the ages given by these rocks are not due to promiscuous partial updating related to the Palaeozoic fold belt further north in Peary Land (see Dawes \& Soper, this report) and that the alteration of the feldspars is caused by thermal effects related to the Carolinidian orogeny acting on the sills either during or later than their emplacement then the ages obtained may be the first evidence for the actual timing of the Carolinidian orogeny. This is discussed more fully by Henriksen \& Jepsen (this report).

$$
\begin{gathered}
982 \pm 19 \mathrm{~m} . \text { y. whole rock ( } 3 \text { determinations) } \\
988 \pm 20 \mathrm{~m} . \text { y. whole rock }{ }^{40} \mathrm{Ar} /{ }^{39} \text { Ar spectrum }
\end{gathered}
$$

GGU 114091. Strongly sericitised tholeiitic quartz dolerite sill from Midsommersø area. $82^{\circ} 12^{\prime} \mathrm{N}, 34^{\circ} 06^{\prime} \mathrm{W}$.

H. F. Jepsen

This sill is regarded as essentially contemporaneous with 114156. It shows less alteration than 114156 and the $\mathrm{K} / \mathrm{Ar}$ age is therefore thought to be closer to the actual age of intrusion of these bodies. The spectrum analysis did not reveal the presence of loosely-bound excess argon in the sample and thus the K/Ar age can be accepted as a minimum figure for the emplacement of these sills.

South Greenland

$$
1066 \pm 32 \mathrm{~m} . \mathrm{y} . \text { whole rock ( } 3 \text { determinations) }
$$

GGU 110039. Contact sample of early Gardar olivine dolerite dyke with tholeiitic affinities, trend 110 , Mato island, Julianehåb district. $60^{\circ} 44^{\prime} \mathrm{N}, 46^{\circ} 14^{\prime}$ W. J.H.Allaart

A subophitic olivine dolerite with olivine, clinopyroxene, plagioclase, Fe oxides and a granophyric intergrowth of alkali feldspar and quartz as primary minerals. Incipient alteration of the olivine and more widespread chlorite-sericite-clay mineral alteration in the feldspars is probably to be interpreted as caused by a slight metasomatism at some time after the dyke injection. The age obtained, which is that of late Gardar activity, supports the general opinion that few if any of the isotopic age determinations on early or mid-Gardar rocks carried out up to the present represent the actual date of intrusion of the bodies. 
East Greenland

$1093 \pm 65 \mathrm{~m}$. y. whole rock (3 determinations)

GGU 99539. Sample from centre of presumed Gardar dolerite dyke trending 100 from Hedenoldsland, Tingmiarmiut area. $62^{\circ} 40^{\prime} \mathrm{N}, 42^{\circ} 38^{\prime} \mathrm{W}$.

D. Bridgwater and K. Gormsen (1969)

A subophitic tholeiitic olivine dolerite composed of olivine, clinopyroxene, uralite, plagioclase, biotite, apatite and $\mathrm{Fe}-\mathrm{Ti}$ oxides with a small amount of alkali feldspar and quartz. There is a slight incipient alteration of the feldspar and olivine. While the $\mathrm{K} / \mathrm{Ar}$ age obtained on this sample can only be regarded as a minimum age for the emplacement of the dyke no serious argon loss is suspected and the age given can be taken as reasonable confirmation of the suggestion that the Gardar igneous province extends north-eastwards beneath the Inland Ice from the type area in South Greenland.

\section{Dykes emplaced during the Ketilidian orogeny}

South-West Greenland

$1774 \pm 35 \mathrm{~m}$. y. whole rock ( 3 determinations)

GGU 70493. Olivine dolerite dyke trending 120, from Frederikshåb district, SouthWest Greenland, $61^{\circ} 50^{\prime} \mathrm{N}, 48^{\circ} 53^{\prime} \mathrm{W}$.

J. D. Friderichsen

An almost completely fresh olivine dolerite with slight tholeiitic tendencies belonging to the regional swarm of thin basic dykes which cut rocks known to be affected by the main phases of Ketilidian deformation but which are metamorphosed in areas where late Ketilidian (Sanerutian) thermal activity took place. There are no geological reasons to suspect either significant argon loss from this sample or the presence of excess argon and the $\mathrm{K} / \mathrm{Ar}$ age can be regarded as a reasonable minimum age for the intrusion of the dyke. This suggests that the main Ketilidian metamorphism took place before $1800 \mathrm{~m}$. y. ago (see also GGU 99497 below).

\section{Early and mid-Precambrian dykes}

South-West Greenland

$$
919 \pm 27 \mathrm{~m} . \text { y. whole rock ( } 3 \text { determinations) }
$$

GGU 76119. Folded and strongly metamorphosed basic dyke from the southern part of the Frederikshåb area. $61^{\circ} 39^{\prime} \mathrm{N}, 48^{\circ} 09^{\prime} \mathrm{W}$.

N. Kelstrup

An amphibolite from an area known to have been affected by the main Ketilidian (c. $1900 \mathrm{~m}$. y.) metamorphism but to the north of rocks known to be affected by late Ketilidian (Sanerutian) metamorphism. The K/Ar age of this rock is clearly that of a younger event. It is close to that given by Ketilidian lavas from Midternæs (Larsen, 1969) and by rocks taken from areas close to the major E-W transcurrent faults cut- 
ting South Greenland. These sporadically distributed ages on rocks from South Greenland which fall between $800-1000 \mathrm{~m}$. y. are taken as evidence for a very slight Grenville overprinting in the area principally controlled by movement along preexisting fault planes.

$$
\begin{aligned}
& 2695 \pm 80 \mathrm{~m} . \text { y. whole rock ( } 3 \text { determinations) } \\
& 2033 \pm 30 \mathrm{~m} . \mathrm{y} \cdot{ }^{40} \mathrm{Ar} /{ }^{39} \mathrm{Ar} \text { whole rock spectrum }
\end{aligned}
$$

GGU 84587. Contact sample of the youngest generation of pre-Ketilidian quartz dolerite dykes trending 109 , from the Frederikshåb area. $62^{\circ} 17^{\prime} \mathrm{N}, 49^{\circ} 35^{\prime} \mathrm{W}$.

B. Chadwick

An almost completely fresh dolerite from the chilled contact of a 30-40 $\mathrm{m}$ wide dyke north of the area seen in the field to have been affected by the Ketilidian metamorphism. The sample consists of clinopyroxene, uralite, biotite, plagioclase, $\mathrm{Fe}$ oxide, apatite, quartz and alkali feldspar. Only very slight alteration is seen in the rock (less than normally present in Mesozoic dykes from the same area). The K/Ar age obtained from this rock was older than expected since these dykes are generally regarded as having been emplaced in the period just before Ketilidian sedimentation. Furthermore other slightly older basic dykes from the same area (GGU 84543, 84535) show considerable excess argon and the sample was therefore run again using ${ }^{40} \mathrm{Ar} /{ }^{39} \mathrm{Ar}$ spectrum methods. The results from this suggest that some loosely-bound excess argon was present in the sample and the K/Ar age obtained was too high. The ${ }^{40} \mathrm{Ar} /{ }^{39} \mathrm{Ar}$ analysis shows a plateau at $2033 \pm 30 \mathrm{~m}$. $\mathrm{y}$. Whether this age is geologically significant is not known with certainty. It could reasonably be interpreted as either the original age of intrusion of the dyke or the age at which a very weak metamorphism affected the dyke.

$$
4880 \pm 97 \mathrm{~m} . \mathrm{y} \text {. whole rock ( } 3 \text { determinations) }
$$

GGU 84543. The centre of a $5 \mathrm{~m}$ wide 2 nd generation pre-Ketilidian altered quartz dolerite trending 65 , Frederikshåb area. $62^{\circ} 20^{\prime} \mathrm{N}, 49^{\circ} 35^{\prime} \mathrm{W}$. Chadwick

An altered quartz dolerite consisting of clinopyroxene, uralite, biotite, plagioclase, iron ore, apatite, quartz and alkali feldspar. Some of the plagioclase shows marked clouding. The $\mathrm{K} / \mathrm{Ar}$ age is clearly too great and considerable excess argon must be present. Attempts to drive off this excess using step heating and ${ }^{40} \mathrm{Ar} /{ }^{39} \mathrm{Ar}$ determinations were not completely successful and the sample still yielded an isotopic age of $3407 \mathrm{~m}$. y. From geological evidence the dyke is known to be younger than $2500 \mathrm{~m}$. y. but older than $1800 \mathrm{~m}$. y.

$$
6300 \pm 126 \mathrm{~m} . \mathrm{y} . \text { whole rock ( } 3 \text { determinations) }
$$

GGU 84535. Contact of $50 \mathrm{~m}$ wide porphyritic basic dyke belonging to the earliest generation of pre-Ketilidian dolerites trending 158 in the Frederikshåb district. $62^{\circ} 22^{\prime} \mathrm{N}, 49^{\circ} 40^{\prime} \mathrm{W}$.

B. Chadwick

A porphyritic dolerite which has been subjected to shearing and hydrothermal 
alteration. The matrix is largely replaced by secondary sericite, calcite, chlorite and alteration products. The plagioclase phenocrysts are clouded. The $\mathrm{K} / \mathrm{Ar}$ age is clearly affected by the presence of considerable excess argon.

\section{$2562 \pm 128 \mathrm{~m}$. y. whole rock ( 3 determinations)}

GGU 87779. A fresh garnetiferous amphibolite from the centre of an approximately $\mathrm{N}$-S basic dyke, Akuliaruseq, north of Sukkertoppen. $65^{\circ} 40^{\prime} \mathrm{N}, 52^{\circ} 50^{\prime} \mathrm{W}$.

B. F. Windley

The centre of a basic dyke with primary garnet amphibolite in the central zone (Windley, in press). The mineralogical peculiarities of these rocks are attributed to crystallisation of basic magmas under abnormal crustal conditions. The $\mathrm{K} / \mathrm{Ar}$ age could be interpreted as the age of intrusion of this body. However a previous $\mathrm{K} / \mathrm{Ar}$ age determination on the gneisses in the area gave an age of about $1800 \mathrm{~m}$. y. (Larsen \& Møller, 1968) and further work is necessary before the possibility of the presence of excess argon can be discounted.

\section{Pre-Ketilidian rocks from South-East Greenland}

$1922 \pm 57 \mathrm{~m}$. y. whole rock ( 3 determinations)

GGU 99497. Metadolerite trending 60 from south side of Tingmiarmiut fjord. $62^{\circ} 38^{\prime} \mathrm{N}, 42^{\circ} 40^{\prime} \mathrm{W}$.

D. Bridgwater and K. Gormsen

A metadolerite cutting pre-Ketilidian gneisses in the Tingmiarmiut region. The metadolerite is cut by fresh appinitic sills and Gardar dykes (see 99539 above). The metamorphism of the dyke is ascribed to the northernmost effects of the Ketilidian orogeny on the east coast. The sample is a dolerite which has undergone partial recrystallisation under amphibolite facies conditions with little or no deformation. Recrystallisation is strong enough to have completely overprinted the original intrusion age of the dolerite. There are no reasons to suggest the presence of excess argon in the sample and the age is taken to be a reasonable figure for Ketilidian metamorphism in the area.

$$
2293 \pm 34 \mathrm{~m} . \mathrm{y} \cdot{ }^{40} \mathrm{Ar} /{ }^{39} \mathrm{Ar} \text { hornblende (2 determinations) }
$$

GGU 99396. Quartz diorite margin of a major net-veined body, Uivaq. $63^{\circ} 02^{\prime} \mathrm{N}$, $41^{\circ} 27^{\prime} \mathrm{W}$.

D. Bridgwater and $\mathbf{K}$. Gormsen

A net-veined diorite-quartz dioritic body regarded as one of the youngest preKetilidian plutonic rocks from SE Greenland. Rock composed of quartz, hornblende, biotite, plagioclase, Fe oxide, sphene and apatite. Slight strain seen in the hornblende. $\mathrm{The}^{40} \mathrm{Ar} /{ }^{39} \mathrm{Ar}$ hornblende age from this rock can be regarded as a minimum age for plutonic activity in this part of Greenland. 


$$
2335 \pm 23 \mathrm{~m} . \mathrm{y} \cdot \text { biotite }{ }^{40} \mathrm{Ar} /{ }^{39} \mathrm{Ar} \text { (2 determinations) }
$$

GGU 99376. Charnockitic gneiss from mouth of Halvdans Fjord, Skjoldungen. $63^{\circ} 12^{\prime} \mathrm{N}, 41^{\circ} 22^{\prime} \mathrm{W}$.

D. Bridgwater and K. Gormsen

An almost completely fresh charnockitic migmatite surrounding hypersthenebearing intrusive rocks on Skjoldungen $\varnothing$. Slight strain is present in the biotite and incipient alteration present in the hypersthene. The ${ }^{40} \mathrm{Ar} /{ }^{39} \mathrm{Ar}$ biotite age obtained from this rock can be taken as a minimum age for the cooling of the high grade complex.

\section{Excess argon}

The excess argon noted from the basic dykes in the Frederikshåb area is the first demonstrated from rocks in Greenland although the anomalously high age of 3070 $\pm 70 \mathrm{~m}$. y. (Larsen, 1969) from a pseudotachylite within the Nagssugtoqidian fold belt is interpreted by GGU geologists as caused by this phenomenon.

The dykes shown to contain excess argon occur in an area $50 \mathrm{~km}$ to the north of the last visible effects of Ketilidian metamorphism. Scattered K/Ar determinations on gneisses in this region give ages of around $2500 \mathrm{~m}$. y., although the boundary between the updated pre-Ketilidian rocks to the south and those apparently unaffected by Ketilidian thermal activity is irregular and not defined closely.

Excess argon has been reported from dykes of a similar general age and setting in the pre-Laxfordian swarms of North-West Scotland (Evans \& Tarney, 1964) and considerable difficulties appear to be present when trying to obtain geologically significant $\mathrm{K} / \mathrm{Ar}$ ages from these rocks. Until the regional distribution of and reason for accumulation of excess argon is understood a certain amount of caution will be necessary in interpreting any abnormally high $\mathrm{K} / \mathrm{Ar}$ ages regardless of whether these are on dykes or on country rocks. This is particularly the case for ages obtained from rocks with low potassium contents.

Before regional studies are carried out it is impossible to be sure whether the excess argon has accumulated in the dyke rocks in question due to their intrusion under abnormal conditions or whether it is a secondary effect due to the migration of argon released from the surrounding gneisses when affected by a younger metamorphic event. Samples 84543 and 84535 show noticeable amounts of recrystallisation attributed to post-consolidational movements along the dyke fissures and it is possible that the introduction of excess argon is related to this shearing movement. However sample 84587 shows practically no recrystallisation and offers no petrological evidence for a marked secondary event affecting the dyke. In this case it would appear that redistribution of argon could be a regional phenomenon rather than one confined to restricted zones of movement.

\section{References}

Allaart, J. H., Bridgwater, D. \& Henriksen, N. in press: The pre-Quaternary geology of South-West Greenland and its bearing on problems of correlation in the North Atlantic. Mem. Am. Ass. Petrol. Geol. 12. 
Andrews, J. R. 1969: A kimberlite dyke in the Nigerdlikasik area, Frederikshåb district. Rapp. Grønlands geol. Unders. 19, 35-37.

Bridgwater, D. \& Gormsen, K. 1969: Geological reconnaissance of the Precambrian rocks of South-East Greenland. Rapp. Grenlands geol. Unders. 19, 43-50.

Evans, C. R. \& Tarney, J. 1964: Isotopic ages of Assynt dykes. Nature, Lond. 204, 638-641.

Jepsen, H. F. 1969: Preliminary report on the stratigraphy of the Precambrian and Eocambrian sediments in the Jørgen Brønlund Fjord - Midsommersø area, southern Peary Land. Rapp. Gronlands geol. Unders. 19, 11-14.

Larsen, O. 1969: K/Ar age determinations. Rapp. Grønlands geol. Unders. 19, 62-67.

Larsen, O. \& Møller, J. 1968: K/Ar age determinations from western Greenland I. Reconnaissance programme. Rapp. Grenlands geol. Unders. 15, 82-86.

Leech, G. B., Lowdon, J. A., Stockwell, C. H. \& Wanless, R. K. 1963: Age determinations and geological studies (including isotopic ages - Report 4). Pap. geol. Surv. Can. 63-17.

Upton, B. G. J. 1965: The petrology of a camptonite sill in South Greenland. Bull. Gronlands geol. Unders. 50 (also Meddr Gronland 169, 11).

Walton. B. 1966: Carbonatite-lamprophyre dykes of Mesozoic age. Rapp. Gronlands geol. Unders. 11, 37-38.

Watt, W. S. 1969: The coast-parallel dike swarm of southwest Greenland in relation to the opening of the Labrador Sea. Can J. Earth Sci. 6, 1320-1321.

Windley, B. F. in press: Primary quartz ferro-dolerite/garnet amphibolite dykes in the Sukkertoppen region of West Greenland. Geol. J.

\section{K/AR AGE DETERMINATIONS ON DOLERITES FROM SOUTHERN PEARY LAND}

\section{N. Henriksen and H. F. Jepsen}

Whole rock $\mathrm{K} / \mathrm{Ar}$ age determinations have been undertaken on two Precambrian discordant sills and one post Lower Cambrian dyke from the Jørgen Brønlund Fjord - Midsommersø area. The rocks, which were collected by H. F. Jepsen, were chosen for age determination to obtain a minimum age of the pre-tillitic sandstones in southern Peary Land and from this to get an indication of the age of the youngest sedimentation in the Carolinidian geosyncline (Haller, 1961).

The two Precambrian discordant sills are representative of a swarm of basic intrusions found throughout a series of unfolded sandstones, which are the oldest exposed rocks in the region. An erosional unconformity separates these sandstones and sills from the unfolded Eocambrian sequence above; at the base of the latter occurs a tillite horizon (Jepsen, 1969). The Eocambrian strata are succeeded by the Lower Cambrian Brønlund Fjord Dolomite (Troelsen 1949, 1956), which is cut by a group of doleritic dykes represented by the third of the dated rocks. 